\title{
First Language Acquisition of Children with Mild Autism: Case Study of Developmental Language Disorders at Palembang Bina Autis Mandiri
}

\author{
Houtman \\ (Corresponding Author) \\ Program Studi Pendidikan Bahasa Indonesia \\ Universitas Muhammadiyah Palembang \\ Email: houtman03@gmail.com \\ Hanni Yukamana \\ Program Studi Pendidikan Bahasa Inggris \\ Universitas PGRI Palembang \\ Email: yukamana1975@univpgri-palembang.ac.id \\ Yenny Puspita \\ Program Studi Pendidikan Bahasa dan Sastra Indonesia \\ Universitas PGRI Palembang \\ Email: yennypuspita673@gmail.com
}

\begin{abstract}
APA Citation: Houtman, H., Yukamana, H., \& Puspita, Y. (2021). First Language Acquisition of Children with Mild Autism: Case Study of Developmental Language Disorders at Palembang Bina Autis Mandiri. Silampari Bisa: Jurnal Penelitian Pendidikan Bahasa Indonesia, Daerah, dan Asing, 4(2), 468-477. https://doi.org/10.31540/silamparibisa.v4i2.1486
\end{abstract}

\begin{abstract}
This study aimed to determine the language acquisition of autistic children who attended Bina Autism Mandiri (BAM) Palembang. The specific target was to obtain information about an autistic child's language acquisition. The study participant was nine years old when the study was conducted. The research used a descriptive qualitative approach because the analyzed data and results were described in words. The data were obtained based on the speech or language of the autistic child through the employment of proficient and listening methods. The analysis was carried out in three stages; the data reduction stage, the data presentation stage, and the inference stage. Research showed that the study participant could pronounce well. However, the meaning of the words this student wanted to say independently was still limited. This student often repeated the imperative types of speech. This type of narrow imperative appeared only in the categories of requests and prohibitions. The acquisition of the $\mathrm{R}$ language, especially the linguistic aspect included in the light group, was still limited. This condition happens because the psychological condition of the student was usually in an uncomfortable state. Painful psychological conditions, for example, being upset and angry, can trigger $\mathrm{R}$ to take physical action in the form of beatings and the spoken vocabulary becomes unclear. It can be inferred that the language acquisition of children with autism is much different from that of normal children.
\end{abstract}

Keywords: language, mild autism, independent autism development 
Houtman, Hanni Yukamana, Yenny Puspita

First Language Acquisition of Children with Mild Autism: Case Study of Developmental

Language Disorders at Palembang Bina Autis Mandiri

\title{
Pemerolehan Bahasa Pertama Anak Autisme Ringan: Studi Kasus Gangguan Perkembangan Bahasa di Bina Autis Mandiri Palembang
}

\begin{abstract}
Abstrak
Penelitian ini bertujuan untuk menjelaskan pemerolehan bahasa anak-anak penderita autisme yang menempuh pendidikan di Bina Autis Mandiri (BAM) Palembang. Tujuan utamanya adalah untuk mencari informasi mengenai pemerolehan bahasa anak-anak penderita autism dengan subjek seorang siswi berusia 9 tahun. Penelitian ini dilakukan dengan pendekatan kualitatif deskriptif karena data yang dianalisa digambarkan dengan kata-kata. Data penelitian diambil melalui bahasa yang diungkapkan oleh anak penderita autis dengan cara proficient and listening methods. Analisis data dilakukan dalam 3 fase: the data reduction stage, the data presentation stage, dan the inference stage. Hasil penelitian menunjukkan bahwa subjek penelitian mampu mengucapkan dengan baik. Akan tetapi, arti dari kata-kata yang ingin diungkapkan secara mandiri masih sangat terbatas. Siswi ini sering mengulang jenis kata imperatif. Jenis kata imperatif yang sering diucapkan hanya dikategori permintaan dan larangan. Kondisi pemerolehan bahasa siswa "R" khususnya di aspek linguistik masih sangat terbatas. Hal ini terjadi apabila siswa dalam posisi dan keadaan yang tidak nyaman. Kondisi psikologis yang tidak menyenangkan misalnya, sedang kecewa dan marah dapat memicu "R" melakukan aksi fisik dengan cara memukul, yang akan menyebabkan kata-kata yang diucapkan menjadi tidak jelas. Bisa disimpulkan pemerolehan bahasa anak-anak penderita autis sangat berbeda dengan anakanak normal pada umumnya.
\end{abstract}

Kata kunci: bahasa, autisme ringan, perkembangan autis mandiri

\section{A. Introduction}

Language is defined as a conventional spoken system, manual (signed), or written symbols used by human beings as the participants or social group members to express themselves within their culture. The language may function as a means of communication, identity, play, imaginative expression, and emotional release (Robins \& Crystal, 2021). Language is a medium for humans to indicate participation and express their performance within society. Without language, a human cannot be part of or belong to a particular community.

Due to the variety of pivotal functions a language serves in human life, the study of language is worth pursuing. Studying the language means diving into human activities since humans will not be separated from using and learning a language in their daily lives (Johnson \& Johnson, 1991). The study of language can be conducted with humans from all walks of life because the use of language is not determined by age. Parents to small children must use language to declare what they want to convey. Nevertheless, young children's language structure is undoubtedly different from the language structure of adults. Young children's language structure is simple because they are still in the early language development and acquisition stage.

The subject of language acquisition and its intricacies is the theme of psycholinguistics study, a psychological study of language that reviews the mental processes that occur in the use and acquisition of language (Carrol, 1986). This study is linked to another discipline such as linguistics, which studies the structure and change of language; neurolinguistics, which studies the relationship between 


\section{Houtman, Hanni Yukamana, Yenny Puspita}

First Language Acquisition of Children with Mild Autism: Case Study of Developmental Language Disorders at Palembang Bina Autis Mandiri

the brain and language; and sociolinguistics, which discusses the relationship between language and social behaviour (Field, 2003).

A child usually utters the words they are exposed from their environment. This phenomenon is commonly called language acquisition. According to Maksan (1993), language acquisition is a process of mastering language carried out by someone (not just children) unconsciously, implicitly, and informally. This statement means that the process of acquiring language does not recognize the teacher or person responsible for achieving the outcomes. There is no particular curriculum or lesson plan, nor is there a specific time and place for learning the language.

The first language or mother tongue is the first language a child hears. The first language is then tried to be spoken by a child by imitation. Even though the meaning of these words is unclear, the ambiguity is caused by imperfect speech instruments. Then over time, because a child does not hear the sound of a language other than his mother tongue, he will only sound his mother tongue.

There is a relationship between the first language acquired by a child and the later child's development. A child who acquires the first language in the form of dirty words will remain to speak destructively because he tends to imitate and later pronounce the words until he reaches adulthood. Furthermore, his behaviour will be affected as well. The research conducted in Japan revealed that the crystals would be in bad shape if the water had spoken bad words.

In contrast, the crystals would be very well-shaped if the water spoke good words. The human body consists of $90 \%$ of water. Therefore, the kind of words that children usually hear, whether good or bad, may shape their personality accordingly.

Moreover, the environment has an essential role in developing a child's first language. Similar to the example mentioned earlier, a child who grows up in a poor social condition tends to be exposed to bad words (Kramer, 2008). Although sometimes, the child does not know the meaning of the words and says the word unconsciously when he cries. The words are then uttered repeatedly and become a habit. Another example is a child who grows up in an environment with many restrictions. He hears only negative words that can affect his mental condition (Kring, et al. 2002). The child will grow up to be a pessimistic child full of fear. They may feel insecure and unable to face problems (Prasetyoningsih, 2016; Bernier \& Gerdts, 2006).

Then, what about the acquisition of the first language of a child with mild autism whose language growth and development process takes place in an inclusive school environment? The school in which the pattern of parental education is used is a treatment that views an autistic child as an average child. Recent research on the language acquisition of children with autism confirmed that autistic children's language development varied between individuals depending on the learning context (Hartley, 2019; Perez, et al., 2020; Hutauruk, 2015). The children also develop their language acquisition relatively not the same way (Swensen et al., 2007; Sari, et al., 2020). Therefore, the study of language acquisition development of an autistic child in an inclusive learning context is worth pursuing (Klin, et al., 2002; Kogan, et al., 2009).

The question of the study was how is the acquisition of the first language of a child with mild autism whose language growth and development process takes

Silampari Bisa: Jurnal Penelitian Pendidikan Bahasa Indonesia, Daerah, dan Asing Vol. 4, No. 2, 2021 


\section{Houtman, Hanni Yukamana, Yenny Puspita}

First Language Acquisition of Children with Mild Autism: Case Study of Developmental Language Disorders at Palembang Bina Autis Mandiri

place in an inclusive school environment? To answer the question, the researcher conducted a study in an inclusive autism school Bina Autism Mandiri Palembang. The subject of the study was nine nine-year-old girl student of the school named "R". The data were also gathered from the parents of " $R$ " and the school therapist.

\section{B. Research Methodology}

This study used the descriptive qualitative method. For triangulation purposes, the data collection was gathered utilizing observation, in-depth interviews and other methods to produce descriptive data about the participant. To obtain the data of the language acquisition of the participant, the video recorded observation was conducted during the study of the subject participant and the therapist. The collected data were transcribed and analyzed using proficient and listening methods.

The second data were the causes of an event experienced by the research subject. To collect the data, several in-depth interviews were conducted with the parents of the subject participant. The interviews were also transcribed and analyzed through stages of analysis. The last data gathered were medical observation collected from $\mathrm{Dr}$. (R), Sp. A and some therapists at B.A.M. Palembang.

The data were analyzed as follows. (1) data that has been obtained from informants either through direct interviews that are non-formal or recorded, as well as from the results of observations were recorded on a separate sheet, (2) the data obtained were then classified based on the aspects studied, (3) classifying the data according to with research needs, (4) analyzing research data according to the actual situation based on research objectives, (5) formulating conclusions and compiling reports.

\section{Results and Discussion \\ 1. Results}

The research data found after conducting research using the proficient and listening method on the language used by $R$, especially the linguistic aspect, are as follows:

Data 1

Speech snippet:

Therapist : Kid, if you want something, what do you say dear? (Nak, kalo ingin sesuatu bilang apa sayang?)

$\mathrm{R} \quad$ : Ask mom, ask mom... (in a soft voice but not looking at the therapist)

(minta bu minta bu... (dengan suara lembut namun tidak menatap terapis)

Data 2

Speech snippet:

Therapist : Honey, if you want to eat what do you want to say? (Sayang, kalo mau makan bilang apa nak?)

$\mathrm{R} \quad$ : Eat mom, eat mom (in a soft voice but not looking at the therapist) (makan bu makan bu (dengan suara lembut namun tidak menatap terapis)

Data 3

Speech snippet:

Therapist : Honey, follow mom dear... after eating you have to... (Nak, ikuti ibu sayang... habis makan harus...) 
Houtman, Hanni Yukamana, Yenny Puspita

First Language Acquisition of Children with Mild Autism: Case Study of Developmental Language Disorders at Palembang Bina Autis Mandiri

$\mathrm{R}$

\section{: Drink mom, drink mom (don't look at the therapist) (Minum bu minum bu (tidak} menatap terapis)

Data 4

Speech snippet:

Therapist : Son, to be smart, you have to defend...(Nak, biar pinter harus bela...)

$\mathrm{R}$

: Studying... (not looking at the therapist and doing other things) (Belajar...

(tidak menatap terapis dan melakukan kesibukan lain)

5. Speech snippet:

Therapist : Read, help, father, mother, write, eat, drink, ball, study (Baca, bantu, ayah, ibu, tulis, makan, minum, bola, belajar)

$\mathrm{R}$

: Read, help, father, mother, write, eat, drink, ball, study (sometimes when the word mother is mentioned, or without a reason $\mathrm{R}$ cries) (baca, bantu, ayah, ibu, tulis, makan, minum, bola, belajar (terkadang saat kata ibu disebut, atau tanpa sebab $R$ menangis)

This is an example of inducement data as an example of vocabulary output obtained from $R$. The results showed that as a person with autism, $R$ looked average in the first and second years of her life. R's parents are aware of the delay in language skills and undoubtedly different ways of playing and interacting with other people. $R$ can be very sensitive or unresponsive to the five senses' stimuli (hearing, touching, smelling, tasting, and seeing). Repetitive behaviours (hand or finger flapping, body shaking and repeating words) may also be present. Behaviour can be aggressive (both toward oneself and others) or very passive. Observation results indicated that previous behaviours that were considered normal might be additional symptoms. In addition to the repetitive play, limited interest and social barriers, some other things that are also permanently attached to $\mathrm{R}$ are unnatural responses to sensory information she receives, for example; noise, light, surface or texture of a specific material and the choice of certain flavours in her favourite food. Some or all of the following characteristics can be observed from $R$ and its spectrum under the lightest to the heaviest conditions.

1. Barriers to communication, for example: speaking and understanding language.

2. Difficulty relating to other people or objects in the vicinity and connecting events.

3. Playing with toys or other objects inappropriately.

4. Difficult to accept changes to routine and recognized environment.

5. Repetitive body movements or specific behavioural patterns.

As a person with autism, $\mathrm{R}$ is limited in her language, so she often repeats words or sentences (echolalia). She also sometimes has high language skills, generally uses limited themes and has difficulty understanding abstract concepts.

\section{Therapy}

Several traditional therapy types have been tested from time to time for $\mathrm{R}$., including learning therapy. The results of interviews with therapists at Bina Autism Mandiri Palembang concluded that therapy should be started early and should be directed at obstacles and delays that every autistic child generally owns, for example, communication and behavioural issues. Comprehensive treatment generally includes; Speech Therapy (Speech Therapy), Occupational Therapy 
(Occupational Therapy) and Applied Behavior Analysis (ABA) to change and modify behaviour.

It is enough to increase the number of memory vocabulary during the therapy process, and it can be understood by $\mathrm{R}$ through action. Following are the results of observations of $R$ while studying at Bina Autism Mandiri Palembang.

A. Social Interaction:

1. Being Unable to establish non-verbal social interactions: eye contact, facial expressions, body position, less focused movements.

2. Having difficulty playing with peers.

3. Showing no empathy, pleasure/interest sharing behavior.

4. Having less ability to hold 2-way social and emotional relationships.

B. Social Communication:

1. Not trying to communicate non-verbally.

2. Being able to talk but not for communication/initiation, egocentric.

3. Showing a weird \& repetitive/stereotyped language.

4. Showing less varied /imaginative, less social imitation.

C. Imagination, flexible thinking and imaginative play:

1. Maintaining one or more interests in a very distinctive and exaggerated manner, both intensity and focus

2. Doing a useless ritualistic activity/routine

3. Showing strange movements that are typical and repetitive. Often very fascinated by certain parts of an object

Some notes on general $\mathrm{R}$ language skills observed during the study are as follows.

1. Showing the ability to imitate all the vocabulary that is taught repeatedly very well

2. pronouncing each vocabulary, do not focus on who asks to talk

3. Showing a tendency not to understand the vocabulary being taught but able to imitate well

4. Singing is a form of anger or irritation towards something

5. Mentioning the repeated words, for example, the word eat will be uttered three times; eat eat eat

6. Acquiring the dominant vocabulary through watching television programs or listening to a tape recorder.

From a series of abilities in acquiring her first language ( $R$ is taught by using Belitung Malay and Indonesian simultaneously as her first language), imperative speech formations become an exciting part of the researcher's observation because these formations are dominant in every interaction with her. As a person with autism, R parrots the adults she hears. This indicates that she has a limited natural mind, meaning she cannot understand the world from the point of view of others. All aspects of communication are difficult to achieve, except for the phonological aspects, which some people with disabilities can still master. The development of language skills is not only experiencing delays but also deviations. Phonologically, the articulation is relatively straightforward, although there are often errors in pronouncing objects. For example, R was substituting or mentioning, removing certain syllables, creating assimilation into other words, adding the wrong syllables. The intonation tends to be flat and wrong in making the emphasis of speech. Her syntactic ability is prolonged because she often imitates sentences or echolalia, repeating sentences that are not relevant to the context. 
The research results regarding the acquisition of imperative utterances uttered by the informant with the initial $R$ were not too many. When saying imperative sentences, $R$ only uses it to interact with her friends at Bina Autism Mandiri (BAM) during breaks, and even then, it is not productive. While in the study room, she was more often busy with herself. Communication with the therapist and her parents or the researcher is limited when she wants something. Imperative utterances, which consist of four parts, namely imperative sentences of request, invitation, prohibition and omission, can be described as follows.

1. Imperative Speech Request

a. "Eat mom... eat mom... eat mom" (while pulling her mother's hand)

b. "Piss bu pee bu pee bu" (while holding pants going to the toilet)

c. "Buy ma'am buy ma'am" (want something)

d. "Drink ma'am drink ma'am" (want to drink)

e. "Take a shower ma'am, take a shower" (want to take a shower)

2. Imperative Utterances of Invitation

a. Not talking (inviting by pulling hands to get out)

3. Speech Imperative Prohibition

a. "Do not open it, do not open it" (one of his relatives came and wanted to open the lid of drinking water for him. This was while half-singing)

b. "No no no no no no" (when his father wants to leave, he leaves)

4. Imperative Utterances of Omission

(There is not any)

Only two are known of the four types of imperative utterances that appear. In this study, concerning the characteristics of autistic children, several important notes accompany R's speech.

a. Imperative formations that appear only contain two words that are pronounced repeatedly.

b. Imperative formations that appear are always accompanied by loud noises and physical actions, such as pulling clothes, hands and even hitting. Neither hitting himself nor hitting others and crying.

c. Imperative formations that appear, especially prohibition, are usually accompanied by singing.

d. R can sing any song well, especially those she heard frequently.

e. Pronunciation of language can be pronounced clearly.

f. The greeting she always calls spontaneously in imperative speech is "bu" (mother).

g. In a state of anger, $\mathrm{R}$ will issue words that are not clear.

The total number of sentences obtained by the informants was seven sentences during one month of research and then divided into imperative speech divisions, namely five sentences of request imperative and two sentences of prohibition imperative.

\section{Discussion}

This research was conducted at BAM Palembang. The data from this study were taken from an autistic student named R. The autistic child is sometimes like a deaf person who cannot hear what other people are talking about, sometimes 
speaks fluently, but what is being said is lost/not understood for a moment. $R$ also does not focus on interacting with other people; for example, if she is invited to communicate, she will answer, but her gaze does not look at the other person. Even she will not respond to what the other person is talking about.

$R$ can say words without a specific purpose and generally expresses without thinking. She said various ways of acting to communicate with other friends. She expresses feelings with her language skills that are different from normal children. $\mathrm{R}$ has difficulty expressing her feelings as a verbal form of communication.

Language as a form of verbal communication is a speech act that varies depending on the level; some are good, and some are lacking. Thus, the variety of speech acts used has unique characteristics different from the others. The problem of spoken language here is crucial because it is to find a picture of the communication it uses. So this research is not merely descriptive because to understand the form of language use, it is necessary to review the relationship with the context that influences it.

In addition, the results of research obtained from BAM (Bina Autism Mandiri) Palembang that most children who follow the therapy experience hyperactive autism. During therapy, children are guided by therapists. Each room has one child and one therapist. This arrangement is made so that a child can focus on receiving what the therapist gives during teaching. In therapy activities for autistic children, children are taught about speech responses, but children are also taught about independence and motor activity when doing each activity.

From the results of interviews with her parents and observations, there are several types of behaviour from $\mathrm{R}$ that can be related to the conclusions of The National Institute of Child Health and Human Development (NICHD) in the United States that must be watched out for and need further evaluation:

1. The child does not show gestural skills (pointing, chest, grasping) until the age of 12 months.

2. Child does not say a word until 16 months old.

3. The child is not able to use two sentences spontaneously at the age of 24 months.

Accurate diagnosis of autism or other related developmental disorders requires a thorough observation of a child's behaviour, communication skills and other developmental abilities. It will be challenging to diagnose because of the various kinds of disorders that can be seen. Observations and interviews with parents are also essential in diagnosis.

\section{Conclusion}

Based on the results of research on language acquisition of autistic children at BAM Palembang named $R$, especially in the linguistic aspect, the conclusion can be described as follows:

1. The acquisition of $R$ language as an autistic child is very different from normal children, including impairment in language or, better known as a developmental disorder, affects language acquisition and use (language deficits).

2. Language acquisition for autistic children at BAM Palembang is also different. Based on the research that examined $R$, it was found that her level of language acquisition was good. In addition to having problems using 
language, $\mathrm{R}$ also has problems understanding language, both used by other people (therapists) and used alone in daily communication practices.

3. In the acquisition of imperative speech, as an autistic child, $R$ is very limited. The imperative appears only in the categories of requests and prohibitions. That, too, is very limited. Imperative formations appear more often in the form of actions.

\section{References}

Bernier \& Gerdts (2006). Autism spectrum disorders: A reference Handbook. Greenwood: Publishing Group.

Carrol, D. W. (1986). Psychology of language. Pacific Grove-California: Brooks/Cole Publishing Company.

Field, J. (2003). Psycholinguistics: A resource book for STUDENTS. New York: Routledge.

Hartley, C. (2019). Language acquisition in children with autism spectrum disorder. https://eprints.lancs.ac.uk/id/eprint/133925/1/_Hartley_2019_Language_acq uisition_in_children_with_autism_spectrum_disorder.pdf

Hutauruk, B. S. (2015). Children first language acquisition at age 1-3 years old in balata. IOSR Journal of Humanities and Social Science, 20(8), 51-57, DOI: 10.9790/0837-20855157

Johnson, D.W. \& Johnson, R.T. (1991). Learning together and alone: Cooperative, competitive, and individualistic learning (3rd Ed). Upper Saddle River, NJ: Prentice-Hall.

Klin, A. et al. (2002). Defining and quantifying the social phenotype in autism. American Journal of Psychiatry, 895-908.

Kogan, et al. (2009). Prevalence of parent-reported diagnosis of autism spectrum disorder among Children in the US, 2007. Pediatrics Journal, 124(5). https://pubmed.ncbi.nlm.nih.gov/19805460/

Kramer, P.D. (2008). Dear abby: Is autism a mental illness? Psychology today. https://www.psychologytoday.com/intl/blog/in-practice/200807/dear-abby-isautism-mental-illness

Kring, et al. (2002). Abnormal psychology. John Wiley \& Sons.

Maksan, M. (1993). Psikolinguistik. Padang: IKIP Padang Pres.

Perez, S. P., Nordhal-Hansen, A., \& Kaale, A. (2020). The role of context in language development for children with spectrum disorder. Language Sciences, 11, https://doi.org/10.3389/fpsyg.2020.563925

Silampari Bisa: Jurnal Penelitian Pendidikan Bahasa Indonesia, Daerah, dan Asing Vol. 4, No. 2, 2021 


\section{Houtman, Hanni Yukamana, Yenny Puspita}

First Language Acquisition of Children with Mild Autism: Case Study of Developmental Language Disorders at Palembang Bina Autis Mandiri

Prasetyoningsih, L. S. A. (2016). Pengembangan tindak bahasa terapi dalam intervensi anak autis spektrum perilaku. LITERA, 15(1). doi:10.21831/ltr.v15i1.9771

Robins, R. H. \& Crystal, D. (2021). Language. Encyclopedia Britannica. https://www.britannica.com/topic/language.

Sari, L. K., Sumarti, E., \& Ramadhani, A. A. (2020). Penguasaan bahasa dalam komunikasi lisan anak autis di UPT Pendidikan Abk Malang. Alfabeta: Jurnal Bahasa, Sastra, dan Pembelajarannya, 3(1), 63-69. doi:10.33503/alfabeta.v3i1.753

Swensen, L. D., Kelley, E., Fein, D., \& Naigles, L.R. (2007). Processes of language acquisition in children with autism: Evidence from preferential looking. Child Development, 78(2), 542-557. 